JOURNAL OF MICROBIOLOGICAL METHODS 61: (2005) 105-126

\title{
Comparison of Image Analysis software packages in the assessment of adhesion of micro-organisms to mucosal epithelium using confocal laser scanning microscopy
}

Rachel O’Mahony ${ }^{a^{*}}$, Christelle Basset ${ }^{\mathrm{a}}$, John Holton ${ }^{\mathrm{a}}$, Dino Vaira ${ }^{\mathrm{b}}$, Ivan Roitt $^{\mathrm{a}}$

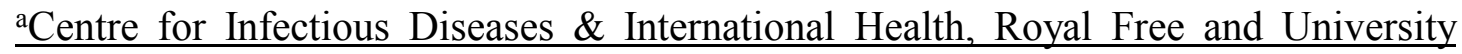
College London Medical School, The Windeyer Building, 46 Cleveland Street, London, W1T 4JF, UK

bepartment of Internal medicine \& Gastroenterology, University of Bologna, Bologna, Italy

* Corresponding author. Tel.: +44-20-76799485; fax: +44-20-76368175. E-mail address: rachelomahony@hotmail.com (R. O’Mahony).

\begin{abstract}
We have compared current image analysis software packages in order to find the most useful one for assessing microbial adhesion and inhibition of adhesion to tissue sections. We have used organisms of different sizes, the bacterium Helicobacter pylori

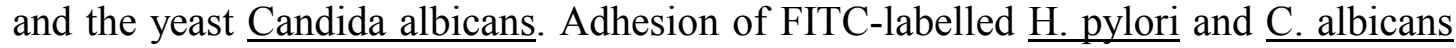


was assessed by confocal microscopy. Four different Image analysis software packages, NIH-Image, IP Lab, Image Pro+ and Metamorph, were compared for their ability to quantify adhesion of the two organisms and several quantification methods were devised for each package. For both organisms the dynamic range that could be detected by the software packages was $1 \times 10^{6}-1 \times 10^{9}$ cells $/ \mathrm{ml}$. Of the four software packages tested, our results showed that Metamorph software, using our 'Region of Interest' method, with the software's 'Standard Area Method' of counting, was the most suitable for quantifying adhesion of both organisms because of its unique ability to separate clumps of microbial cells. Moreover, fewer steps were required. By pre-

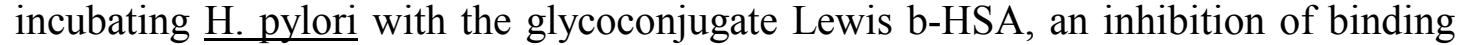
of $48.8 \%$ was achieved using $250 \mathrm{ug} / \mathrm{ml}$ Lewis b-HSA. The method we have devised using Metamorph software, provides a simple, quick and accurate way of quantifying adhesion and inhibition of adhesion of microbial cells to the epithelial surface of tissue sections. The method can be applied to organisms ranging in size from small bacteria to larger yeast cells.

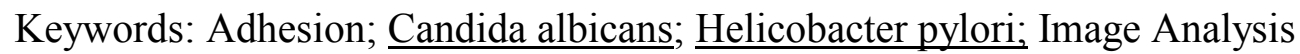

\section{Introduction}

Some superficial mucosal infections may become chronic leading to a persistent acute inflammatory reaction and in some cases persistent symptoms for the patient. In the case of infection with Helicobacter pylori, the host is unable to eradicate the organism, despite a florid neutrophil response. In the case of recurrent Candida vaginitis, the host is similarly unable to eradicate the organism from the mucosa. In both cases, the effectiveness of current anti-microbial therapy is being compromised by an increasing level of resistance of both $\underline{H}$. pylori and Candida albicans to the appropriate agents. It is with this in mind that alternative strategies are being 
investigated and one such strategy is to target adhesion, the primary step in the infection process (Basset et al., 2003). Microbes frequently adhere to tissue by specific ligand-receptor interactions and once adherent lead to tissue damage and a subsequent host response.

H. pylori colonises the stomach of over half the human population. Although most infected people are asymptomatic, in $5-20 \%$ of those infected, severe gastroduodenal diseases, including ulcers of the stomach and duodenum, gastric lymphomas and adenocarcinomas, may occur (Montecucco and Rappuoli, 2001). A number of putative adhesin-receptor interactions have been proposed for $\underline{H}$. pylori (Evans and Evans, 2000). The best described interaction is that between the BabA outer membrane protein found on the surface of the bacterium and the Lewis b blood group antigen which is expressed by gastric epithelial cells. Borén et al. (1993) used fluorescently labelled $\underline{H}$. pylori cells and showed localised adherence to the epithelium of stomach sections by fluorescence microscopy. They were able to inhibit adhesion of $\underline{H}$. pylori to stomach expressing the Lewis $b$ antigen (Lewis $b$ stomach) by first pre-incubating bacteria with Lewis $b$ neoglycoconjugates (analogues of the receptor) before adding the bacteria to the tissue sections. Adhesion and inhibition were quantified by manually counting the number of bacteria bound to the epithelial surface. Other studies have confirmed this (Borén et al., 1994; Ilver et al., 1998).

C. albicans, a yeast, is responsible for a wide range of diseases including vaginal infections. Approximately three-quarters of all women will suffer from vaginal candidiasis (VC) at least once in their lifetime and up to $25 \%$ of these women will experience recurrent disease (recurrent vaginal candidiasis, RVC), which is distressing and difficult to treat (Mardh et al., 2002). Adhesins that have been studied include Hwp1 (Sundstrom, 2002), mannoproteins, which bind to fucose or Nacetylglucosamine (GlcNAc) glycosides on human buccal and vaginal epithelial cells (Calderone, 1993; Critchley and Douglas, 1987a and b) and secretory aspartyl proteinases (Watts et al., 1998). The secretory aspartyl proteinase SAP2 has been found to be important in vaginal infection in a rat vaginitis model (De Bernardis et al., 1999) and SAPs 1-3 have generally been shown to be important in mucosal adherence (Monod and Zepelin, 2002).

As microbial adhesion is the primary step in the pathogenic process, it has received considerable attention because of the possibility of inhibiting this first interaction and thus preventing infection. The process of adhesion, usually occurring in the presence of hydrodynamic and shear forces, which tend to limit the deposition of microorganisms, has been mathematically analysed in both flow and static systems (Sjollema et al., 1989). Several studies have been performed with a parallel plate device designed to mimic hydrodynamic forces (van Kooten et al., 1992; Millsap et al.,1999; Gomez-Suarez et al., 2001), although much work has been performed in the absence of these forces.

Many methods for studying bacterial adhesion have been used (An et al., 1997), which include direct microscopic counts after suitable staining, flow cytometry and image analysis of fluorescent labelled organisms (Clyne et al., 1997; Grivet et al., 1999), haemagglutination (Goldhar, 1995), attachment to immobilised molecules on thin-layer chromatography plates (Saitoh et al., 1991), radiolabelling (Mackowiak et al., 1984), ATP quantification (Robrish et al., 1977), and immunological methods (Ofek et al., 1995). Although valuable, these studies are artificial as they do not mimic tissue very closely and the cells may not be representative of those occurring in the target tissue. A number of studies have investigated adhesion to whole tissue sections (Borén et al., 1993; Falk et al., 1993; Reinhard et al., 2000) and although not ideal (due to the processing of the tissue), they are likely to be more representative of the 
natural microbial-host interaction.

A fundamental requirement in determining adhesion and inhibition of adhesion is quantification of binding. When studying binding to tissue sections, a common method of quantification that has been used is direct microscopic counts of labelled (usually fluorescent) organisms, although image analysis methods have also been applied, as direct visual counts are time consuming.

Image analysis methods have a broad application in microbiology and have been used to quantify microorganisms in geological material (Tobin et al., 1999), in food processing (Hood et al., 1997), in the petrochemical industry (Williamson et al., 1989), for the enumeration of marine plankton (Pernthaler et al., 2003) and biomass determination (Pons et al., 2000) as well as biomedical applications, such as analysis of bacterial motility (Gualtieri et al., 1988), morphology, physiological processes in bacteria following infection (Goldstein et al., 1988), colony counting (Corkidi et al., 1998) and adhesion (Sjollema et al., 1990; Reinhard et al., 2000).

Image analysis of adherent microorganisms is usually performed following specific stains either for DNA or some antigenic cell wall components using a fluorescent labelled antibody. Image analysis comprises three main steps: object delineation, signal to background differentiation by setting a threshold value and quantification, either by enumeration of objects or intensity of signal- usually fluorescence. Initially a comparison of visual counts to output of the image analysis system are performed to validate the - image analysis system. In dynamic systems, such a flow chamber, differentiation between static adherent organisms and free-flowing organisms have to be taken into account, usually by multiple image analysis or extended threshold values.

The image analysis system at its simplest may comprise a microscope with attached digital camera or colour-CCD devise, frame grabber, computer and analysis software. The microscope may be computer controlled so that it automatically scans the required fields and in some systems focussing is also automated. Microscopes frequently used are epifluorescent microscopes or confocal laser scanning microscopes.

Various software packages have been utilised e.g. NIH Image (Reinhard et al., 2000), Image Pro Plus (Barthelson et al., 1999) Prism (Schonholzer et al., 2002), ICONIX (Corkidi et al., 1998) or written in-house (Jansen et al.,1999). When analysing adherence of irregular shaped organisms or organisms adherent to turbid solids the accuracy of the counts can be increased by using an artificial neural network to quantify the organisms (Wit et al., 1998).

Currently, there are a number of image analysis software packages available but no analysis of which ones are appropriate to assessing microbial adhesion to tissue sections. The aim of this study was therefore to compare current image analysis software packages in order to find the most useful one for analysing microbial adhesion to tissue sections, in particular a yeast and a bacterium, which are of different sizes.

\section{Materials and Methods}

\subsection{Tissue}

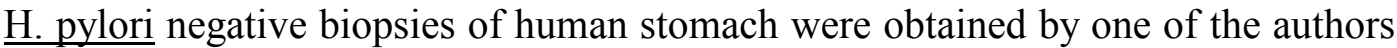
(DV) with the consent of the Ethics Committee, St Orsola Hospital, Bologna. Vaginal tissue was obtained from oophorectomised rats (Charles Rivers Inc USA) maintained 
in pseudo-oestrus by subcutaneous injections of 50mg oestradiol benzoate given every second day. An appropriate Ethical Licence was obtained for the study.

\subsubsection{Stomach sections}

Formalin-fixed stomach biopsies, whose epithelial cells expressed the Lewis b blood group antigen, were used. Five micrometer sections of stomach were cut using a Leica SM2400 rocking microtome. Sections were collected on polished glass slides coated with Vectabond (Vector Laboratories, UK). After preliminary studies, the following antigen-retrieval method was used to expose the antigen. The sections were deparaffinised (3mins in Xylene then Isopropanol, Sigma, UK), rehydrated in a graded series of alcohols and digested in $\alpha$-Chymotrypsin solution, $\mathrm{pH} 7.8\left(\begin{array}{ll}0.1 \% & \alpha-\end{array}\right.$ chymotrypsin $/ 0.1 \%$ calcium chloride, Sigma, UK) at $37^{\circ} \mathrm{C}$ for $10 \mathrm{mins}$, to expose the Lewis $b$ antigen. To expose the Lewis a antigen, after deparaffinising, the sections were boiled for 5 mins in an $800 \mathrm{~W}$ microwave in plastic coplin jars containing $15 \mathrm{mls}$ of Citrate buffer, pH 6.0 (100M sodium citrate tribasic dihydrate, Sigma, UK). The Lewis phenotype of the tissue was determined by standard immunohistochemical staining using the DAKO EnVision Plus HRP kit (DAKO, UK) with anti-Lewis a (Le a) and anti-Lewis b (Le b) antibodies generously donated by Dr J Bara, Hôpital StAntoine, Paris, France. Both antibodies were supplied at a concentration between 1$5 \mathrm{ug} / \mathrm{ml}$. For use in Lewis typing experiments, the anti-Le antibodies were diluted 1/10 and $1 / 50$ for the anti-Le a and anti-Le $b$, respectively.

\subsubsection{Vaginal sections}

Rat vaginal tissue was embedded in OCT (Tissue-Tek, UK) and 'snap-frozen'. Five micrometer sections were cut using a cryostat (Leica CM1900, UK) and keratinisation of the epithelial cells was confirmed by modified Papanicolaou staining (Elzay and Richmond, 1983).

\subsection{Microbial isolates}

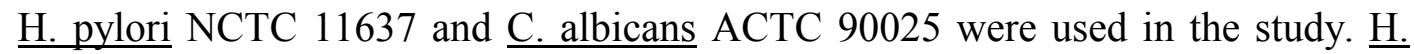
pylori was grown for 2 days on Columbia blood agar at (Oxoid, UK) $37^{\circ} \mathrm{C}$ under microaerobic conditions (Stevenson et al., 2001). C. albicans was grown on Columbia blood agar for 24 hours at $37^{\circ} \mathrm{C}$. The number of bacterial cells was determined by obtaining viable counts of serial dilutions and measurement of the optical absorbance at $600 \mathrm{~nm}$ (Ultrospec II, LKB, UK) of a suspension of bacterial cells to prepare a standard curve for $\underline{H}$. pylori. All studies thereafter used the same concentration of organism based upon its absorbance. For $\mathrm{C}$. albicans the number of yeast cells was determined for each experiment by a microscopic count using a haemocytometer.

\section{Fluorescent labelling of microbes}

For both organisms suspensions of $1 \times 10^{9}$ cells $/ \mathrm{ml}$ were made in $1 \mathrm{ml}$ carbonate buffer $\left(0.15 \mathrm{M} \mathrm{NaCl} / 0.1 \mathrm{M} \mathrm{Na}_{2} \mathrm{CO}_{3}, \mathrm{pH} 9.0\right)$. Five microlitres of a $10 \mathrm{mg} / \mathrm{ml} \mathrm{FITC}$ (fluorescein isothiocyanate isomer I, Sigma, UK) solution in DMSO (dimethyl sulfoxide, Sigma, UK) were added to each bacterial suspension and $20 \mu$ of FITC were added to each yeast suspension. They were then incubated for 1hour with continuous shaking. The suspensions were then washed three times with phosphate buffered saline (PBS: $\mathrm{NaCl} 8.0 \mathrm{~g} / \mathrm{L} ; \mathrm{K}_{2} \mathrm{HPO}_{4} 1.21 \mathrm{~g} / \mathrm{L} ; \mathrm{KH}_{2} \mathrm{PO}_{4} 0.34 \mathrm{~g} / \mathrm{L}, \mathrm{pH} 7.4$ ) containing 0.05\% Tween 20 (PBST) (Sigma, UK) and then the pellets were resuspended in PBS. Labelling was confirmed by flow cytometry (FACSCalibur, 
Becton Dickinson, UK). All incubation and washing steps were carried out in the dark at room temperature.

\subsection{Binding Assay}

Tissue sections were incubated for $30 \mathrm{mins}$ in a humid atmosphere with $200 \mu 1$ per slide of blocking buffer (PBST/2\%BSA). Sections were then washed three times by placing in a slide rack in $350 \mathrm{mls}$ PBST on a rotator for $10 \mathrm{mins}$. The FITC-labelled microbes were decimally diluted in blocking buffer to give concentrations between $1 \times 10^{10}$ to $1 \times 10^{2}$ cells $/ \mathrm{ml}$ and $200 \mu$ l were added to each slide and incubated in a humid atmosphere for 1hour. After the incubation, slides were washed in PBST as previously. Two hundred microlitres of propidium iodide (PI, $5 \mu \mathrm{g} / \mathrm{ml}$ ) was added and each slide incubated for 3 mins. Slides were then washed twice in PBST, air-dried and mounted with Vectashield (V-1000, Vector Laboratories, UK). All incubation and washing steps were carried out in the dark at room temperature and two tissue sections were used for each concentration of organism.

Binding Inhibition Assay for Helicobacter pylori

To inhibit H. pylori adhesion, Lewis b-HSA (Isosep, Sweden) was diluted in suspensions of FITC- $\underline{H}$. pylori to give final concentrations of $0,10,250,500$ and 1000 $\mu \mathrm{g}$ Lewis b-HSA $/ \mathrm{ml}$ and $1 \times 10^{8}$ bacteria $/ \mathrm{ml}$. This was then incubated with continuous shaking for 2 hours at room temperature in the dark and washed with blocking buffer. The suspension was then incubated with the stomach sections as mentioned before. Three tissue sections were used for each concentration. The experiment was performed twice.

\subsection{Quantification of binding}

\subsubsection{Image capture}

Sections were observed using a Laser Scanning Confocal Microscope (Zeiss: Axiovert $100 \mathrm{TV}$ ) with a 10 Zeiss Plan-Neofluar objective for observing $\underline{\mathrm{C} \text {. albicans }}$ on vaginal sections and a $\mathrm{x} 20$ Zeiss LD-ACHR objective for observing $\underline{\mathrm{H} \text {. pylori on }}$ stomach sections. The excitation wavelengths were 488 (for FITC) and 568nm (for PI). $522 \mathrm{~nm}$ and $605 \mathrm{~nm}$ band-pass filters were used to acquire FITC emission and PI emission respectively. Digital images ( 512 x 512 pixels) of the sections were captured using a Biorad Lasersharp 2000 Confocal Laser Scanning System. Images were converted to TIF files for processing. Two photographs showing adjacent areas of the tissue were taken for each tissue section.

\subsubsection{Image analysis software}

The following Image Analysis software were compared:

NIH-Image (version 1.62) This is public domain software for the Macintosh, and is available as a free download from the internet on the NIH's website at $<\mathrm{http}$ ://rsb.info.nih.gov/nih-image $>$. There is also a PC version available at http://www.cs.ubc.ca/spider/ladic/executor.html

IP-Lab (version 3.6) Professional image analysis software package produced by Scanalytics Inc., USA. An evaluation version is available free on the internet on the Scanalytics website at: <http://www.scanalytics.com/download/index.shtml $>$. The full version is available for Macintosh and Windows operating systems and can be purchased from Scanalytics Inc. 
$\underline{\text { Image Pro+ (version 4.1) }}$ Professional Image analysis software, produced by Media Cybernetics Inc. USA.

Metamorph (version 4.5r) Professional Image Analysis software, produced by Universal imaging Corporation, USA.

\subsubsection{Image processing and Analysis}

From each digital image taken, a red (PI) image showing only the tissue, a green (FITC) image showing only the microbial cells and a combined red and green image showing the tissue and microbial cells, were produced. Using these digital images we have devised 4 methods for quantifying adherent microbial cells using each of the Image Analysis software packages.

\section{Method 1: Counts by Merging Images}

The number of micro-organisms adhering to the surface of the tissue is determined by subtracting the sum of the [background (glass/non-tissue) number of microorganisms (B) + micro-organisms adherent to the lamina propria (L)] from the total number of micro-organisms (C). This method gives a value for only those organisms attached to the epithelial surface.

Method 2: Counts by Image Dilation

This is similar to the above method except that after carrying out the "Fill" command, the tissue image is dilated by a set number of pixels (For $\underline{C}$. albicans the dilation was set to 10 pixels and for $\underline{\mathrm{H}}$. pylori, which are smaller cells, the dilation was set to 5 pixels). As before by merging the red and green images, counts of cells in the whole image, the background and the tissue can be obtained and hence the number of adherent microbial cells calculated.

Method 3: Counts by Area

In this method, the area of at least 20 individual organisms is found using the "Wand" tool (IP Lab \& NIH Image) or by using the "area" measurement (Image Pro+ and Metamorph) and the average calculated (A). Both the (red and green) and tissue (red) images are filled in with the wand or equivalent tools, so that the area with (B) and without $(\mathrm{C})$ the adherent organisms is outlined. The areas of both are found. The number of organisms adherent to the epithelial surface is found by subtracting the area of the tissue image with (B) and without (C) the adherent organism divided by the area of a single organism (A).

Method 4: Counts by Region of Interest

In this method a region of interest (ROI) is drawn by hand around the microbial cells that are directly adhering to the epithelial surface using the "wand" tool. Using the "Count" tool the number of microbial cells is provided in the highlighted region.

Metamorph has an additional "Standard Area" method of obtaining the counts which automatically divides clusters of microbial cells into the number of composite microbial cells by first calculating the mean size of one organism.

\subsubsection{Comparison of software packages}

The number of adherent microbial cells per mm of epithelial surface in the section was calculated for each of the software packages so that the results of each package could be compared. The length of the epithelial surface of each photo was calculated by outlining the tissue in the image and using the software to calculate its length (in pixels). In order to convert the units from pixels into millimeters, a digital photo of a stage micrometer on the confocal microscope was taken, and using the software packages, the number of pixels represented by $1 \mathrm{~mm}$ was obtained. All values obtained 
for length of epithelial surface were subsequently converted into mm.

Additionally, other data taken into consideration when comparing the software packages were the cost, availability of the package, ease of use in terms of number of manipulations, correlation between image manipulation and the number of adherent organisms and finally which packages were able to perform the various methods listed above.

\subsubsection{Operator Error}

In order to determine the amount of error introduced by the operator when performing quantification, epithelial length measurements and counts of adherent cells for the dynamic range for both $\underline{H}$. pylori and $\underline{C}$. albicans was carried out three times on three separate occasions, using the best software package and method (Metamorph with the ROI and Standard area method of counting). The mean of the three counts was calculated and standard error determined.

\subsubsection{Manual method of counting}

From each digital image the number of adherent cells was also counted manually using the microscope. This was performed by two independent observers and the counts obtained averaged.

The length of the epithelial surface of each digital image was calculated manually by measuring the length of the edge of the tissue in the image (in $\mathrm{cm}$ ). In order to convert the length obtained on the digital image into the actual length of the tissue, the image on the stage micrometer was measured manually, and the number of $\mathrm{cm}$ represented by $1 \mathrm{~mm}$ of the graticule was obtained. All values obtained manually for length of epithelial surface on the digital image were subsequently converted into $\mathrm{mm}$.

\section{Results}

Of the 4 methods used to quantify adherence, only some software packages were able to perform all of them and these are outlined in Table 1. Of those software packages that could perform the same method of quantification the commands were slightly different. The whole set of sequences for each method of each of the packages is given in the Appendix.

\subsection{Dynamic Range}

For both organisms the dynamic range that could be detected by the software packages was between $1 \times 10^{6}$ and $1 \times 10^{9}$ cells/ml (Figures 1 and 2). At concentrations less than $1 \times 10^{6}$ cells $/ \mathrm{ml}$ there were no adherent cells in either of the different tissue sections. Conversely, at $1 \times 10^{10}$ cells/ml there were so many organisms on the tissue sections that it was difficult to see the epithelial surface.

\subsection{Comparison of Software Packages with manual count}

The accuracy of the software packages was compared to the manual method of counting used as the gold standard. The method that could be performed by all the packages was chosen (ROI method) as the comparator. Metamorph was found to give the most accurate calculation of epithelial length, compared to the other packages and manual method (it included all the small indentations in the epithelial surface). Therefore in order to compare the ability of the packages to count the number of adherent cells, the epithelial length measurement was kept constant (i.e. the 
measurement obtained by metamorph was used for all methods of counting, manual and software). Counts of adherent organisms was performed 3 times. The results for this show that Metamorph gives the highest count of cells for both $\underline{H}$. pylori and $\underline{C}$. albicans over the dynamic range (Figures 3 and 4), with a correlation coefficient of 1.00 and 0.95 (respectively) with the manual count. The other three software packages

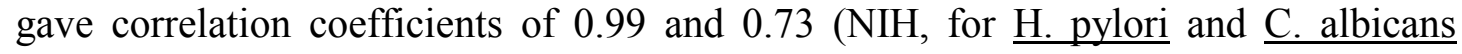
respectively) and 0.89 (Image Pro $^{+}$, for $\underline{\text { C. albicans }}$

\subsection{Comparison between the software packages}

The advantages and disadvantages of the different software packages were compared and are summarised in Table 2.

\subsubsection{Helicobacter pylori - quantification of binding}

None of the methods employed by NIH-Image to quantify the dynamic range resulted in a linear increase in the number of adherent cells with increase in $\underline{H}$. pylori concentration. With IP Lab only Method 3 could be used and this again did not yield a linear increase in the number of adherent cells with increase in $\underline{H}$. pylori concentration. Quantification was unable to be performed on the images using Image Pro+, because the cells were too small to be counted. Using Metamorph, an increase in number of adherent cells with $\underline{H}$. pylori concentration was obtained using the ROI Normal method. Although the ROI Standard Area method produced a slight decrease in adherent cell numbers at $1 \times 10^{9}$ cells $/ \mathrm{ml}$, the number was not very different from adherent cells at a concentration of $1 \times 10^{8}$. Although the Merging (Normal) and Area methods also showed an increase in adherence with concentration of bacteria, the absolute numbers of adherent cells were much lower than those obtained with the ROI method.

\subsubsection{Candida albicans - quantification of binding}

As for $\underline{H}$. pylori none of the methods employed by NIH-Image to quantify the dynamic range showed a linear increase in the number of adherent cells with increase in concentration of $\underline{C}$. albicans. IP-Lab produced the opposite result, as the concentration of $\mathrm{C}$. albicans was increased, the number of adherent cells counted decreased. Using Image Pro+, both the dilation and ROI method resulted in an increase in number of adherent cells with increase in concentration. Metamorph, using the ROI method with standard area method of counting, was able to effectively separate clumps of cells and this was the only method that produced an increase in adherent cells with increase in $\underline{\mathrm{C} \text {. albicans }}$ concentration for this software package.

\subsection{Operator Error}

Only a small amount of error is introduced by the operator when quantifying the number of adherent organisms using image analysis software (Figures 5 and 6). The standard error ranged from 0.1 to 3.4 and all of the three counts at each concentration

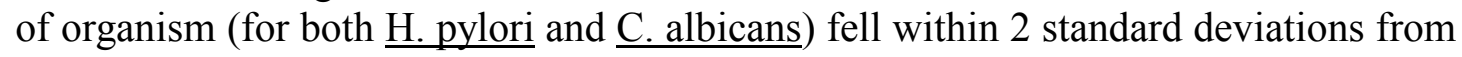
the mean.

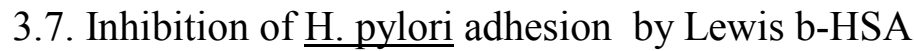

Using Metamorph, ROI and standard area method, the binding of $\underline{H}$. pylori to Lewis b stomach and its inhibition with soluble Le b-HSA was investigated. The 
mean inhibition of binding from the two experiments was $8.3 \%$ with $10 \mu \mathrm{g} / \mathrm{ml}, 48.6 \%$ with $250 \mu \mathrm{g} / \mathrm{ml}, 10.6 \%$ with $500 \mu \mathrm{g} / \mathrm{ml}$ and $19.6 \%$ with $1000 \mu \mathrm{g} / \mathrm{ml}$ of the Le-b conjugate (Table 3 ).

\section{Discussion}

As a consequence of the increasing prevalence of antibiotic resistance, alternative therapeutic strategies are being sought for mucosal infections. One such strategy is the development of agents that inhibit adhesion, the primary step in the pathogenic process. Various image analysis software packages are available to quantify the adhesion of micro-organisms to mucosal surfaces, but there is no published comparison of which software package is the simplest and most accurate to use. We have therefore compared 4 image analysis packages with a manual method of counting as a "gold-standard", using micro-organisms of differing sizes- a bacterium, Helicobacter pylori and a yeast, Candida albicans.

Of all the software packages tested, Metamorph (using the ROI method with standard area method of counting) was found to be the best for counting microbial adherence to epithelial surfaces of tissue sections for the two organisms employed in this study. Image Pro+ was the second best software package. Metamorph is able to take account of clumps of adherent microbial cells into its final cell count, as is Image Pro+ [this package was used in the adhesion studies of Barthelson et al., (1999)], but it does so less effectively. Moreover, Image Pro+ is unable to count $\underline{H}$. pylori cells, because they are too small to be detected, which confirms Metamorph as the software package of choice. The error introduced by the investigator when performing quantification is small and thus should have very little effect on the accuracy of the resulting counts. Using Metamorph software for quantification is also better than counting manually because it is faster and more accurate at measuring both the epithelial length and the number of adherent cells, especially when they are clustered together as it is difficult to manually estimate the number of cells comprising the clusters. In none of the cases were the counts over the dynamic range linearly related to the concentration of organism added to the section. This is of course what one may expect particularly at high concentrations as receptors may be blocked and organisms may clump.

Using confocal microscopy and image analysis we have demonstrated that the binding of $\underline{H}$. pylori strain NCTC 11637 to the epithelial surface of Lewis b stomach sections, can both be inhibited by the soluble glycoconjugate Lewis b-HSA and quantified by the image analysis software Metamorph. Maximum inhibition was achieved using $250 \mathrm{ug} / \mathrm{ml}$ and at higher concentrations than this, inhibition was less. It may be that large amounts of glycoconjugate has an agglutinating effect on the bacteria and thus more bind to the epithelial surface and therefore inhibition is less at higher concentrations. In fact, more clumps of bacteria were seen on the epithelial surface of the tissue sections from the higher concentrations of Le b-HSA (500 and $1000 \mathrm{ug} / \mathrm{ml}$ ) compared to the control and lower concentrations of Le b-HSA.

The method we have devised, using Metamorph software (using the ROI method and the standard area method of counting) is a simple, quick and accurate way of quantifying adhesion and inhibition of adhesion of microbial cells to the epithelial surface of tissue sections. It is an improvement on the method developed by Reinhard et al., (2000) who used NIH-Image for the same purpose. Unlike NIH-Image, Metamorph is able to separate clumps of cells into individual organisms, producing a more accurate count. We have also demonstrated that the method can be applied to 
organisms ranging in size from small bacteria to larger yeast cells.

\section{Acknowledgements}

We would like to acknowledge the European Union on EC contract QLK2-CT2001-01216 (ADRI) for financial support. We wish to thank Mariam Andrawiss (Dept. of Immunology and Molecular Pathology) for help and advice with the confocal microscope and confocal software and Nalini Singh (Dept. of Histopathology) for technical assistance with paraffin sectioning.

\section{References}

An, Y.H., Friedman, R.J., 1997. Laboratory methods for studies of bacterial adhesion. J. Microbiol. Methods 30, 141-152.

Barthelson, R., Hopkins, C., Mobasseri, A., 1999. Quantitation of bacterial adherence by image analysis. J. Microbiol. Methods 38,17-23.

Basset, C., Holton, J., O'Mahony, R., Roitt, I., 2003. Innate immunity and pathogenhost interaction. Vaccine 21, S12-23.

Borén, T., Falk, P., Roth, K. A., Larson, G., Normark, S., 1993. Attachment of Helicobacter pylori to human gastric epithelium mediated by blood group antigens. Science 262,1892-1895.

Borén, T., Normark, S., Falk, P., 1994. Helicobacter pylori: molecular basis for host recognition and bacterial adherence. Trends Microbiol. 7, 221-228.

Calderone, R.A., 1993. Recognition between Candida albicans and host cells. Trends Microbiol. 1, 55-58.

Clyne, M., Thomas, J., Weaver, L., Drumm, B., 1997. In vitro evaluation of the role of antibodies against Helicobacter pylori in inhibiting adherence of the organism to gastric cells. Gut 40, 731-738.

Corkidi, G., Diaz-Uribe, R., Folch-Mallol, J.L., Nieto-Sotelo, J., 1998. COVASIAM: an image analysis method that allows detection of confluent microbial colonies and colonies of various sizes for automated counting. Appl. Environ. Microbiol. 64, 14001404.

Critchley, I.A., Douglas, L.J., 1987a. Isolation and partial characterization of an adhesin from Candida albicans. J. Gen. Microbiol. 133, 629-36.

Critchley, I.A., Douglas, L.J., 1987b. Role of glycosides as epithelial cell receptors for Candida albicans. J. Gen. Microbiol. 133, 637-43.

De Bernardis, F., Arancia, S., Morelli, L., Hube, B., Sanglard, D., Schafer, W., Cassone, A., 1999. Evidence that members of the secretory aspartyl proteinase gene family, in particular SAP2, are virulence factors for Candida vaginitis. J. Infect. Dis. 179, 201-208. 
Elzay, R. P., 1983. A modification of the Papanicolaou exfoliative cytology stain to demonstrate keratin in paraffin-block tissue sections. Oral Surg. Oral Med. Oral Pathol. 56, 51-53.

Evans, D. J. Jr., Evans, D. G., 2000. Helicobacter pylori Adhesins: Reviews and Perspectives. Helicobacter 5, 183-195.

Falk, P., Roth, K. A., Borén, T., Westblom, T. U., Gordon, J. I., Normark, S., 1993. An in vitro adherence assay reveals that Helicobacter pylori exhibits cell lineagespecific tropism in the human gastric epithelium. Proc. Natl. Acad. Sci. USA 90, 2035-2039.

Goldhar, J., 1995. Erythrocytes as target cells for testing bacterial adhesins. Methods Enzymol. 253, 43-50.

Goldstein, E., Donovan, R.M., Kim, Y., 1988. Applications of computerized microscopic image analysis in infectious diseases. Rev. Infect. Dis. 10, 92-102.

Gomez-Suarez, C., Busscher, H.J., van der Mei, H.C., 2001. Analysis of bacterial detachment from substratum surfaces by the passage of air-liquid interfaces. Appl. Environ. Microbiol. 67, 2531-2537.

Grivet, M., Morrier, J.J., Souchier, C., Barsotti, O., 1999. Automatic enumeration of adherent streptococci or actinomyces on dental alloy by fluorescent image analysis. $\mathrm{J}$ Microbiol. Methods 38, 33-42.

Gualtieri, P., Ghetti, F., Passarelli, V., Barsanti, L., 1988. Microorganism track reconstruction: an image processing approach. Comput. Biol. Med. 18, 57-63.

Hood, S.K., Zottola, E.A., 1997. Adherence to stainless steel by foodborne microorganisms during growth in model food systems. Int. J. Food Microbiol. 37, 145-153.

Ilver, D., Arnqvist, A., Ogren, J., Frick, I. M., Kersulyte, D., Incecik, E. T., Berg, D. E., Covacci, A., Engstrand, L., Borén, T., 1998. Helicobacter pylori adhesin binding fucosylated histo-blood group antigens revealed by retagging. Science 279, 373-377.

Jansen, G.J., Wildeboer-Veloo, A.C.M., Tonk, R.H.J., Franks, A.H., Welling, G.W. 1999. Development and validation of an automated, microscopy based method for enumeration of groups of intestinal bacteria. J. Microbiol. Methods 37, 215-221.

Mackowiak, P.A., Marling-Cason, M., 1984. A comparative analysis of in vitro assays of bacterial adherence. J. Microbiol. Methods 2, 147-158.

Mardh, P.A., Rodrigues, A.G., Genc, M., Novikova, N., Martinez-de-Oliveira, J., Guaschino, S., 2002. Facts and myths on recurrent vulvovaginal candidosis--a review on epidemiology, clinical manifestations, diagnosis, pathogenesis and therapy. Int. J. STD. AIDS. 13, 522-39.

Millsap, K,W., Bos, R., van der Mei, H.C., Busscher, H.J., 1999. Adhesion and

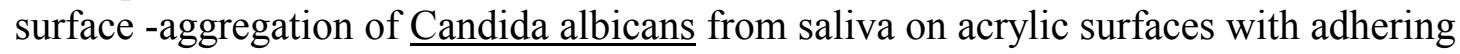


bacteria as studied in a parallel plate flow chamber. Antonie Van Leewenhoek. 74, 351-359.

Monod, M., Borg-von Zepelin, M., 2002. Secreted proteinases and other virulence mechanisms of Candida albicans. Chem. Immunol. 81, 114-28.

Montecucco, C., Rappuoli, R., 2001. Living dangerously: How Helicobacter pylori survives in the human stomach. Nat. Rev. Mol. Cell. Biol. 2, 457-66.

Ofek, I., 1995. Enzyme linked immunosorbent based adhesion assays. Methods Enzymol. 253, 528-536.

Pernthaler, J., Pernthaler, A., Amann, R., 2003. Automated enumeration of groups of marine picoplankton by fluorescence in situ hybridization. Appl. Environ. Microbiol. 69, 2631-2637.

Pons, M.N., Vivier, H., 2000. Biomass quantification by image analysis. Adv. Biochem. Eng. Biotechnol. 66, 133-184.

Reinhard, J., Basset, C., Holton, J., Binks, M., Youinou, P., Vaira, D., 2000. Image analysis method to assess adhesion of Helicobacter pylori to gastric epithelium using Confocal laser scanning microscopy. J. Microbiol. Methods 39:179-187.

Robrish, S.A., Kemp, C.W., Bowen, W.H., 1977. Use of extractable adenosine triphosphate to estimate the viable cell mass in dental plaque samples obtained from monkeys. Appl. Environ. Microbiol. 35, 743-749.

Saitoh, T., Natomi, H., Zhao, W.L., Okuzumi, K., Sugano. K., Iwamori, M., Nagai, Y., 1991. Identification of glycolipid receptors for Helicobacter pylori by TLCimmunostaining. FEBS Lett. 282, 385-387.

Schonholzer, F., Hahn, D., Zarda, B., Zeyer, J., 2002. Automated image analysis and in situ hybridization as tools to study bacterial populations in food resources, gut and cast of Lumbricus terrestris L. J. Microbiol. Methods. 48, 53-68.

Sjollema, J., Busscher, H.J., Weerkamp, A.H., 1989. Experimental approaches for studying adhesion of microorganisms to solid substrata; applications and mass transport. J. Microbiol. Methods 9, 79-90.

Sjollema, J., van der Mei, H.C., Uyen, H.M., Busscher, H.J., 1990. Direct observations of cooperative effects in oral streptococcal adhesion to glass by analysis of the spatial arrangement of adhering bacteria. FEMS Microbiol. Lett. 57, 263-269.

Stevenson, T.H., Castillo, A., Lucia, L.M., Acuff, C.R., 2001. Growth of Helicobacter pylori in various liquid and plating media. Lett. App. Microbiol. 30, 192-196.

Sundstrom, P., 2002. Adhesion in Candida spp. Cell Microbiol. 4, 461-469.

Tobin, K.J., Onstott, T.C., De Flaun, M.F., Colwell, F.S., Fredrickson, J., 1999. In situ imaging of microorganisms in geological material. J. Microbiol. Methods 37, 201213. 
van Kooten, T.G., Scakenraad, J.M., vab der Mei, H.C., Busscher, H.J., 1992. Development and use of a parallel plate flow chamber for studying cellular adhesion to solid surfaces. J. Biomed. Mater. Res. 26,725-738.

Watts, H., Cheah, F., Hube, B., Sanglard, D., Gow, N., 1998. Altered adherence in strains of Candida albicans harbouring null mutations in secreted aspartic proteinase genes. FEMS Microbiol Lett. 159, 129-35.

Williamson, F.A., Palframan, K.R., 1989. An improved method for collecting and staining microorganisms for enumeration by fluorescent microscopy. J. Microsc. 154, 267-272.

Wit, P., Busscher, H.J., 1998. Application of an artificial neural network in the enumeration of yeasts and bacteria adhering to solid substrata. J. Microbiol. Methods 32, 281-290. 
Table 1

Methods of Quantification able to be performed by software packages

\begin{tabular}{|l|l|l|l|l|}
\hline Method & NIH Image & IP Lab & Image Pro+ & Metamorph \\
\hline Merging & - & - & $*$ & $*$ \\
\hline Dilation & $*$ & - & $*$ & $*$ \\
\hline Area & $*$ & $*$ & $*$ & $*$ \\
\hline ROI & $*$ & - & $*$ & $*$ \\
\hline
\end{tabular}

-: not able to be performed

$*$ :can be performed

Table 2

Comparison of software packages - advantages and disadvantages

\begin{tabular}{|c|c|c|c|c|c|}
\hline & \multicolumn{5}{|c|}{ SOFTWARE PACKAGE } \\
\hline \multirow[t]{2}{*}{ CRITERIA } & \multirow{2}{*}{\multicolumn{2}{|c|}{$\begin{array}{l}\text { NIH-Image IP-Lab } \\
\text { Metamorph }\end{array}$}} & \multirow{2}{*}{\multicolumn{3}{|c|}{ Image Pro+ }} \\
\hline & & & & & \\
\hline \multicolumn{2}{|c|}{ Can obtain counts for $\underline{\text { C. albicans }}$ and $\underline{\text { H. pylori }}$} & Yes & Yes & & \\
\hline & \multicolumn{4}{|l|}{ Yes } & \\
\hline \multirow{3}{*}{ No. of steps required to obtain counts } & & & & & \\
\hline & Many & Few & Few & & ew \\
\hline & & & & & \\
\hline \multicolumn{3}{|c|}{ Displays results on screen so can see if counts are correct } & Yes & I & $\mathrm{o}$ \\
\hline & Yes & Yes & & & \\
\hline \multirow{2}{*}{ Can separate clumps of cells } & No & No & \multicolumn{3}{|c|}{ To some extent } \\
\hline & \multicolumn{4}{|l|}{ Yes } & \\
\hline \multirow{3}{*}{ Counts are accurate } & No & No & Fairls & & \\
\hline & \multicolumn{4}{|l|}{ Very } & \\
\hline & & & & & \\
\hline \multirow[t]{2}{*}{ Cost } & Free & Free dem & ersion & & \\
\hline & \multirow{2}{*}{\multicolumn{2}{|c|}{ Expensive $>£ 1000$}} & \multicolumn{3}{|c|}{ Expensive $>$} \\
\hline$£ 1000$ & & & & & \\
\hline
\end{tabular}

Table 3

Inhibition of $\mathrm{H}$. pylori adhesion to Le $\mathrm{b}$ stomach sections by Le $\mathrm{b}-\mathrm{HSA}$. The $\%$ Inhibition of two experiments is shown.

\begin{tabular}{|l|l|l|l|l|l|}
\hline \% Inhibition & Leb-HSA Concentration $(\mathbf{u g} / \mathbf{m l})$ & \\
\hline & $\mathbf{0}$ & $\mathbf{1 0}$ & $\mathbf{2 5 0}$ & $\mathbf{5 0 0}$ & $\mathbf{1 0 0 0}$ \\
\hline Experiment 1 & 0 & 16.7 & 27.7 & 19.7 & 27.5 \\
\hline Experiment 2 & 0 & 0 & 69.5 & 1.5 & 11.6 \\
\hline Mean & $\mathbf{0}$ & $\mathbf{8 . 4}$ & $\mathbf{4 8 . 6}$ & $\mathbf{1 0 . 6}$ & $\mathbf{1 9 . 6}$ \\
\hline
\end{tabular}



a)

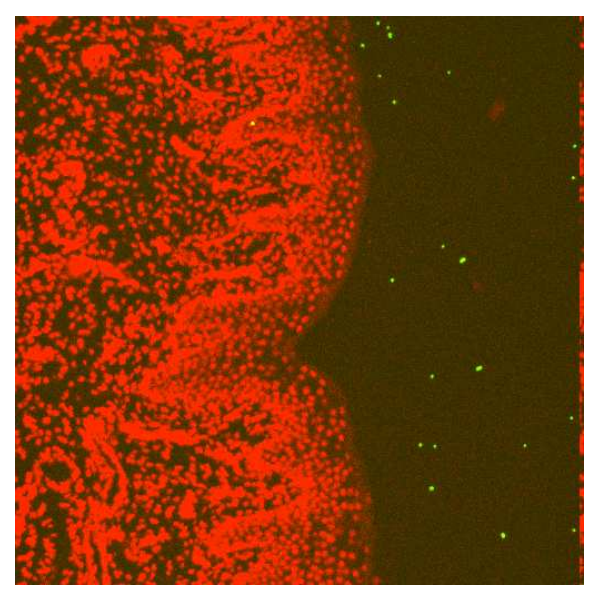

c)

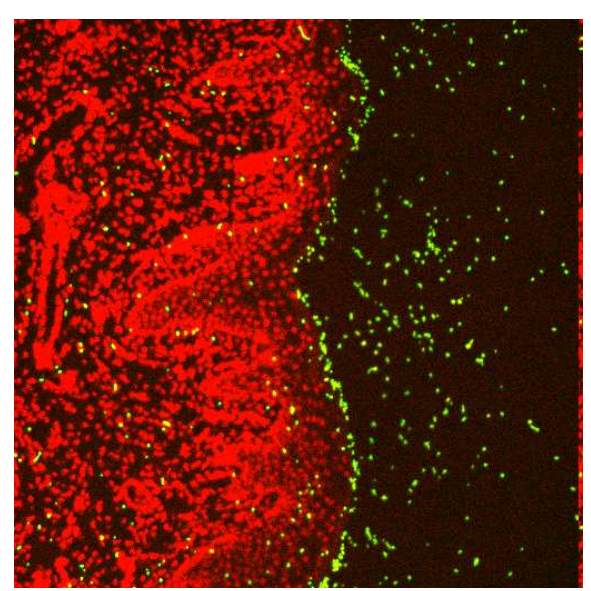

b)

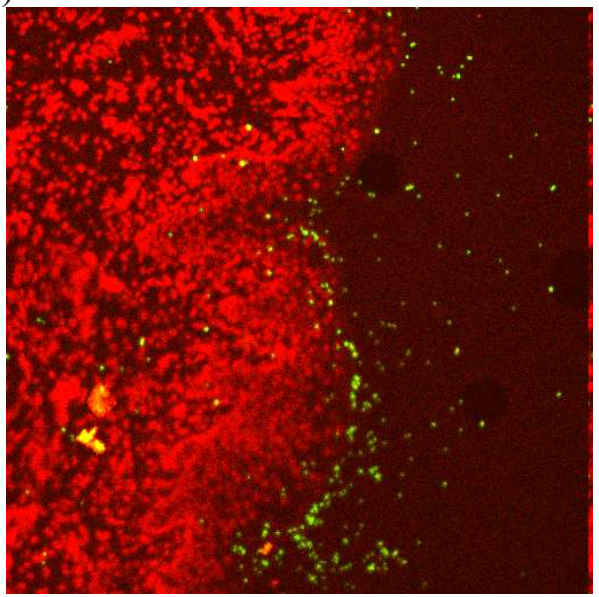

d)

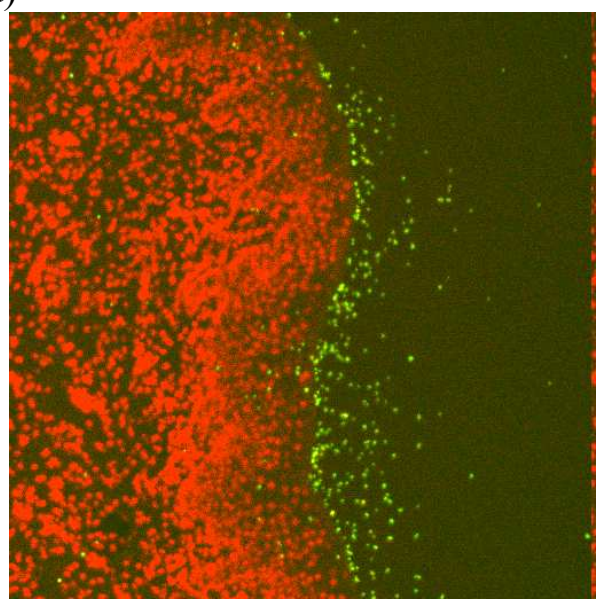

Figure 1: Confocal Images showing dynamic range of adherent C. albicans (cells $/ \mathrm{ml}$ ). Concentrations represent the number of organisms added to the tissue sections.
a) $1 \times 10^{6}$
b) $1 \times 10^{7}$
c) $1 \times 10^{8}$
d) $1 \times 10^{9}$ 

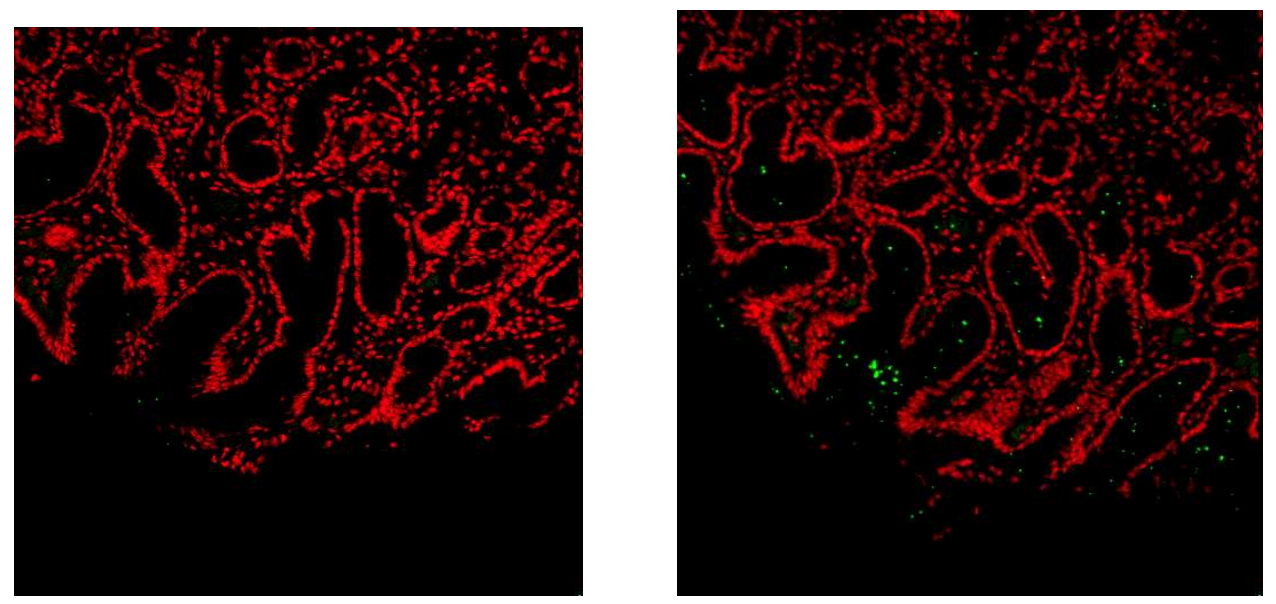

c)

d)
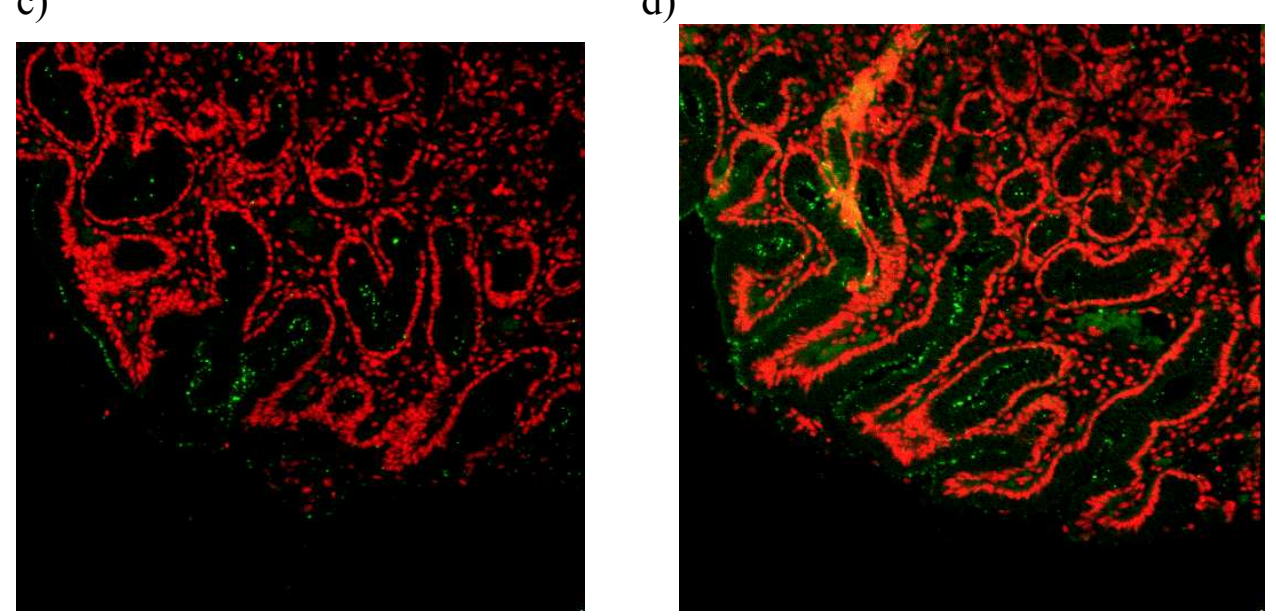

Figure 2: Confocal Images showing dynamic range of adherent $\underline{H}$. pylori (cells $/ \mathrm{ml}$ ). Concentrations represent the number of organisms added to the tissue sections.
a) $1 \times 10^{6}$
b) $1 \times 10^{7}$
c) $1 \times 10^{8}$
d) $1 \times 10^{9}$ 
Figure 3: Comparison of manual method of counting with software packages (ROI methods), using epithelial length as calculated by Metamorph for each method.

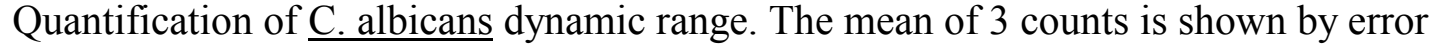
bars. 
Figure 4: Comparison of manual method of counting with software packages (ROI methods), using epithelial length as calculated by Metamorph for each method.

Quantification of $\underline{H}$. pylori range. The mean of 3 counts is shown with error bars. 
Figure 5: $\underline{H}$. pylori dynamic range - Operator error. Quantification was performed three times on separate occasions. The mean of the 3 counts is shown with error bars. 


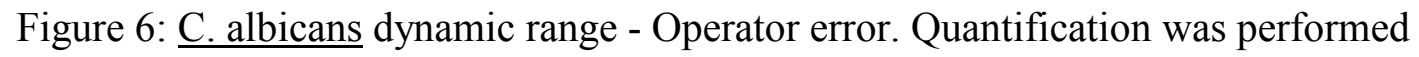
three times on separate occasions. The mean of the 3 counts is shown with error bars. 


\section{Appendix}

\section{IMAGE ANALYSIS PROTOCOLS - NIH IMAGE 1.62}

$\mathrm{B}+\mathrm{W}=$ black and white

\section{METHOD 1: SURFACE COUNTS BY DILATION}

(Based on paper by Reinhard et al., 2000). Also needed is the software package Adobe Photoshop. There is a free trial download on the internet of Version 6.0, the version used in the paper.

A. Process the Green (FITC) image of the microbial cells

1. Threshold. MENU: Options $>$ Threshold. Adjust so all cells are thresholded.

2. Convert to 32-Colour Image.

MENU: Options $>$ Colour Tables $>32$ Colours

Save as 'Green Processed 1'

3. Make Greyscale and Fill background in white. USE ADOBE PHOTOSHOP 5.0

MENU: Image $>$ Mode $>$ Greyscale

Select 'Fill' tool in tool bar, select white and click in background of image which then turns white.

Save as 'Green Processed 2'

4. Open in NIH-Image, Threshold and binarise.

MENU: Options > Threshold (Set to 1.0)

MENU: Process $>$ Binary $>$ Make Binary

Save as 'Green Processed 3'

B. Process the Red (PI) image of the tissue

1. Threshold. MENU: Options $>$ Threshold. Adjust so all the issue is included in threshold.

2. Invert, Sharpen and Binarise image - use closed binary function to fill in spaces in the image. MENU: Edit $>$ Invert

MENU: Process $>$ Sharpen

MENU: Process $>$ Binary (Use default count 4, Iterations 1) $>$ Close

Save as 'Red Processed 1'

\section{Fill in tissue in black.}

Use paintbrush tool and click on black colour in LUT window.

Save as 'Red Processed 1b'

4. Dilate Red Image so can count particles on surface of tissue section, particles outside dilated edge are regarded as background. Dilate 10 pixels for $\underline{C}$. albicans and 5 pixels for $\underline{H}$. pylori (10 pixel dilation used in Reinhard's paper for $\underline{H}$. pylori).

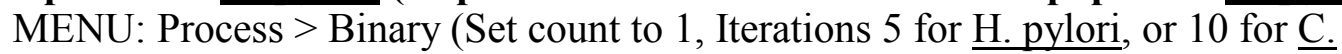
albicans) $>$ Dilate. Save as 'Red Processed 2'

C. Count all cells in image

1. Open Green Image (Green Processed 3) and Threshold.

2. Count Cells.

MENU: Analyse > Analyse Particles (Select all options and min. size 
1)

MENU: Analyse $>$ Show Results

D. Count cells in background + surface of tissue

1. Merge the Green Processed Image of the microbial cells, with the Red

Processed Image where the tissue has been filled in.

Open Green Processed 3 and Red Processed $1 b$.

MENU: Stacks $>$ Windows to stack (use $<$ and $>$ keys to move between images).

MENU: Stacks $>$ Average (of this stack)

MENU: Options > Threshold (adjust so entire image is $\mathrm{b}+\mathrm{w}$ ).

2. Count cells.

MENU: Analyse > Analyse Particles

MENU: Measure $>$ Show Results

E. Count cells in background only

1. Open Green processed Image and the Red Processed image which has been filled in and dilated.

Open Green Processed 3 and Red Processed 2.

MENU: Stacks $>$ Windows to stack (use $<$ and $>$ keys to move between images).

MENU: Stacks $>$ Average (of this stack)

MENU: Options $>$ Threshold (adjust so entire image is $b+w$ ).

2. Count cells.

MENU: Analyse $>$ Analyse Particles

MENU: Measure $>$ Show Results

F. Calculate the number of adherent cells in the image

Subtract the value obtained in E (background cell count) from the value obtained in D (background + surface cell count). This will give number of cells adhered to the surface of the tissue.

\section{METHOD 2: SURFACE COUNTS BY AREA}

A. AREA OF TISSUE PLUS ADHERENT CELLS

1. Open Combined Red + Green image and make greyscale.

MENU: Options > Greyscale

2. Threshold so tissue and microbial cells are white, and background is black.

3. Make Binary.

MENU: Options > Threshold - adjust so particles correct size

MENU: Process $>$ Binary $>$ Make Binary

4. Fill in the tissue completely in white

Use tools in toolbox after having selected 'white' in the LUT window with the eyedropper tool that appears once the tools for filling have been selected.

5. Invert the Image, because the software only counts cells/areas that are black. Must threshold and binarise first.

MENU: Options > Threshold

MENU: Process $>$ Make Binary

MENU: Edit > Invert - The tissue has now turned black.

6. Outline tissue+cells.

Select 'Wand' tool and click this on the image in the black tissue. This has now 
become outlined.

7. Measure area of this tissue.

MENU: Analyse > Options (select 'Area' measurement).

MENU: Analyse > Set scale. Choose 'pixels' as units.

MENU: Analyse $>$ Measure

MENU: Analyse $>$ Show results.

\section{B. AREA OF TISSUE}

Open the Red Image of the tissue that has been filled in (Red Processed 1b). Follow steps 5 - 7 as outlined in section A (miss out steps $1-4$ because the image is already filled in).

\section{MEAN AREA OF A MICRIOBIAL CELL}

1. Open Green Image and make greyscale.

MENU: Options > Greyscale

2. Threshold (to 1.0 so cells are correct size and same size as used in methods to obtain other counts so no variation is introduced) and Binarise.

MENU: Options > Threshold

MENU: Process $>$ Binary $>$ Make Binary

\section{Measure area of cells.}

Select 'Wand' tool and click on individual microbial cells. After clicking on a cell, it becomes outlined. Then can measure the area of the cell by MENU: Analyse > Options (select 'Area' as the measurement).

MENU: Analyse > Measure

MENU: Analyse $>$ Show results

\section{METHOD 3: SURFACE COUNTS BY DRAWING SPECIFIC REGION OF INTEREST AROUND ADHERENT CELLS}

\section{A. CREATE AN ROI AROUND ADHERENT CELLS ONLY}

1. Open green image made $b+w$ (Green processed 3 ).

2. Open the Red+green image alongside this - so can see which particles are on the surface so know which to include in the ROI.

3. On the green image, draw a ROI around the cells that are adherent to tissue surface - use 'Trace region' $R O I$ tool in toolbox.

4. Threshold and Binarise. May have to threshold again after binarising.

5. Select units of measurement as Pixels.

6. Count cells.

$$
\text { MENU: Analyse > Set Scale. Choose 'pixels'. }
$$

MENU: Analyse $>$ Analyse Particles

MENU: Analyse $>$ Measure

MENU: Analyse $>$ Show Results

B. MEASURE LENGTH/PERIMETER OF EPITHELIUM - the part on which the selected adherent cells were measured.

1. Open the red filled image mad $b+w$ (Red Processed $1 b)$.

2. Open Red+Green Image alongside this as a reference for where the epithelial edge 
is that the cells were counted on.

3. Fill in black (make straight square lines) the parts of the tissue edge not needed/used to count cells on.

4. Threshold and binarise - may need to re-threshold after binarising.

5.Outline. Click on 'Wand' tool and then click wand on black tissue.

6. Measure. MENU: Analyse $>$ Options - choose length/perimeter.

MENU: Analyse > Measure - Results are displayed in the 'Info' box.

7. Use the pointer or wand tool to rest on the image edges to get lengths of borders of image/parts of the image that were included in the perimeter measurement but want to exclude from the measurement since they were not the parts of the tissue surface that were used for the cell count. Subtract these values from the total to give the true length of surface across which the adherent cells were counted.

\section{MEASUREMENT OF LENGTH OF EPITHELIAL SURFACE - TO CALCULATE NUMBER OF ADHERENT CELLS PER UNIT LENGTH OF TISSUE}

1. Open Red (PI) Image that has been filled in black (Red Processed 1b)

2. Threshold so can perform measurements.

MENU: Options > Threshold (Adjust so all tissue is filled).

\section{Choose measurements.}

MENU: Analyse > Options (select 'Perimeter/Length')

MENU: Analyse >Set scale (select 'pixels' as the units)

\section{Outline tissue.}

Select 'wand' tool in toolbox. This is the automatic outlining tool.

Click wand inside the tissue required to be measured. Tissue outline should be highlighted.

\section{Measure.}

MENU: Analyse > Measure

6. Subtract from the total perimeter value given, the length of the lines that are not wanted to be included in the measurements (i.e.) the borders of the image window. This will then give a value for the length of the tissue surface alone. These lengths to subtract can be obtained by moving the mouse pointer to the end of the lines that want to exclude. Displayed in the 'Info' box are the $X-Y$ co-ordinates of the position of the mouse pointer. The $X-Y$ co-ordinates represent the pixel number, thus the length (no. of pixels) of the line wanted to be excluded from the total perimeter, can be obtained. Use the 'Zoom' option (magnifying glass symbol in the toolbox) to zoom in on the image so the mouse pointer can be positioned more accurately at the edges of the lines. To 'unzoom' go to MENU: Edit > Unzoom.

\section{IMAGE ANALYSIS PROTOCOLS -}

\section{$\underline{\text { IP LAB }}$}

This software cannot perform counts therefore use the 'Area Method' (find area of adherent cells and divide by mean size of one cell to obtain a cell count) to overcome this. 


\section{METHOD: SURFACE COUNTS BY AREA}

\section{A. AREA OF TISSUE+ADHERENT CELLS}

1. Open the Red + Green (PI and FITC combined) image.

2. Make Greyscale. MENU: Enhance $>$ Colour to Grayscale.

3. Segment Image. MENU: Analyse > Segmentation. Select 'White'.

4. Fill image in black. Double click on the 'Square' tool and select 'fill'. Select 'black' in the segment colour box. Draw squares in the image and fill inside each with black. Must fill even small dots of white with black and even the very edges of the Image window (zoom in to do this).

5. Binarise. Choose segment colour 'White' on the tool box. MENU: Math > Binarise.

6. Binarise and segment again to select the tissue.

MENU: Math > Binarise. Select 'White'.

MENU: Analyse > Segmentation. Select 'Black' tissue fills in black.

\section{Outline tissue + adherent cells.}

In toolbox: Select 'Wand' tool, select 'Segmentation tools' and select colour as 'Black'.

Click on black part of image. The cells that were attached to the surface of the epithelium have also been included in the outline.

8. Measure area of the tissue + adherent cells (outlined part of image).

MENU: Analyse > Set measurements. Select 'Area'.

MENU: Analyse > Measure ROI.

\section{B. AREA OF TISSUE}

Repeat steps outlined in 'A' but use the Red (PI) image.

\section{MEAN AREA OF ONE CELL}

1. Open the Green (FITC) Image.

2. Make Greyscale. MENU: Enhance $>$ Colour to Grayscale.

3. Segment. MENU: Analyse > Segmentation. Select colour as 'Green'.

4. Fill cells in white. Zoom in using magnifying glass tool.

Choose the 'Segment Rectangle' tool.

Double click on its icon in the tool box and in the dialog box that appears select 'Pen size' as ' 1 ' and tick the 'fill' option. Click on 'ok'. Select 'White' as the colour in the tool box. Click on each pixel within each cell and they fill with white.

\section{Measure area of cells.}

Select 'Wand' tool in toolbox, select 'White' as the colour and select 'segmentation tools'. Click wand on each cell filled in white and measure after selecting each one by doing MENU: Analyse > Measure ROI.

6. Calculate the Mean size. Results are displayed in 'Measurement results' window.

\section{CALCULATE NUMBER OF ADHERENT CELLS}

To calculate the number of adherent cells, subtract the value obtained in 'B' (area of tissue) from the value obtained in ' $A$ ' (area of tissue + adherent cells). The value that is obtained from this is the total AREA of the adherent cells. In order to obtain the NUMBER of adherent cells, divide the TOTAL AREA of adherent cells by the MEAN AREA of one cell (value obtained in ' $\mathrm{C}$ '). 
1. Outline the tissue of the red image that has been filled in (Use 'Wand' tool, after selecting black as the ROI colour in the toolbox, and click on the tissue part of the image).

2. Measure. MENU: Analyse $>$ Set Measurements. Select 'Area' and in 'Perimeter'. select 'pixel method'.

3. MENU: Analyse > Measure ROI. Measurement results are displayed in a separate window.

4. To subtract the lengths of the edges of the image that are not to be included in the meaurement, obtain the values by taking the $\mathrm{x}$ and $\mathrm{y}$ co-oordinates of the edges. These are displayed in the window that appears when select MENU: Windows > Show Status. Use the pointer to obtain the position of the edges.

\section{IMAGE ANALYSIS PROTOCOLS - IMAGE PRO PLUS}

NOTE: When using processed images that have already been saved, before carrying out any functions, first the images may need to be segmented (always set segment value to 105$)$.

\section{METHOD 1: SURFACE COUNTS BY MERGING IMAGES}

\section{A. PROCESS THE RED IMAGE}

1. Open red (PI) image.

2. Enhance contrast so can see red more clearly.

a) Click on 'Contrast Enhance' tool on tool bar and Increase the GAMMA contrast channel so red becomes brighter but with little increase in background noise.

b) Press 'Apply'.

3. Make Image greyscale. MENU: Edit $>$ Convert to $>$ Greyscale 8

4. Increase contrast again as for step 2.

5. Threshold - makes image b+w. MENU: Process $>$ Threshold - set at 1.0 so black is at darkest level. Click 'Apply mask'. Then close dialog box.

6. Fill in Image.

a) Create AOI - select required shape on toolbar and draw on image.

b) MENU: Edit > Fill - in 'Fill' dialog box select 'black' and press 'fill'.

c) Click 'New AOI' in tool bar, then draw new AOI and fill as before. Repeat until whole tissue is filled in black.

d) Outline by hand the parts of the edge need to fill in black - Use 'Irregular AOI' tool, in the same way filling as before.

e) Fill in background in white - same method as a) - d).

\section{B. PROCESS GREEN IMAGE}

1. Increase Gamma contrast of green channel to 5.4.

2. Segment Image. MENU: Process $>$ Segmentation. Set green channel to 105, choose 'Black on White'.

C. COUNT OF TOTAL CELLS IN IMAGE

1. Open Green Processed Image. 
2. Fill over any dirt. Choose the 'Autotrace' tool from tool bar. Draw a ROI with it around the dirt and fill in the same colour as the background. MENU: Edit > Fill.

3. Count Cells. MENU: Measure $>$ Count/Size. In the count/size window select the following options:

DISPLAY OPTIONS: Outline style: Outline Choose colour 'Red'.

Label Style: Object No.

Label Colour: Blue

OBJECT OPTIONS: Select: 8-Connect, Pre-Filter, Fill Holes,

Clean Borders: No borders. Click 'Ok'

4. Select Measurements. In Count/size window:

MENU: Measure > Select Measurements: Area and Count (adjusted). Select

'AutoDark objects' if cells are black, if cells are white, select 'Autobright

objects'.

5. Count cells. Click 'Count' and counts are displayed.

6. Separate clumps/clusters. In count/size window:

MENU: Edit > Autosplit.

MENU: Edit > Watershed split.

Updated Count is automatically displayed.

D. COUNT OF CELLS IN BACKGROUND

1. Open Red filled image and the green processed image.

2. Merge Images. MENU: Acquire $>$ Sequence tools $>$ Merge

MENU: Acquire $>$ Sequence tools $>$ Average.

3. Decrease gamma contrast of white channel. Only the cells in the background remain visible.

4. Segment this Image.

5. Fill over any dirt in the background. Fill with the background colour.

6. Count cells. MENU: Measure $>$ Count/size. In the Count/size window select:

'Auto bright objects'.

7. Split clusters of cells. In Count/size window do:

MENU: Edit > Autosplit

MENU: Edit > Watershed split. When 'Watershed split' is done, the actual tissue becomes divided up into segments. Count the number of segments this has been divided up into and subtract this value from the total, so that the value obtained only represents the number of cells rather than the tissue as well as cells.

\section{E. COUNTS OF CELLS ON TISSUE}

1. Merge Red filled tissue image with Green processed image.

2. Average.

3. Increase gamma contrast. Only cells on tissue remain visible.

4. Count cells. Select 'Auto dark objects'.

\section{F. CALCULATE THE NUMBER OF ADHERENT CELLS}

Subtract the value obtained in ' $\mathrm{D}$ ' and ' $\mathrm{E}$ ' (number of cells in the background and on the tissue) from the total number of cells in the image (Method 1, part ' $C$ ') and this will give the number of cells adhering to the tissue surface. 


\section{METHOD 2: SURFACE COUNTS BY AREA}

\section{A. AREA OF RED FILLED TISSUE}

1. Open Red filled image made $\mathrm{b}+\mathrm{w}$.

2. Outline tissue. Click on 'Auto trace' tool. Click on 'Wand'. Then click the wand inside the black tissue. Tissue becomes outlined.

3. Measure.

MENU: Measure > Count/size. In Count/size window do:

MENU: Measure > Select Measurements. Choose 'Area' and click 'ok'. Choose

'Auto Dark objects'.

Options: Label style $>$ Measurement. Clean Borders $>$ None.

Then press 'Count'.

4. View measurements.

MENU: View > Measurement data. Area is displayed.

B. AREA OF RED+GREEN IMAGE

1. Open Red+Green image. Make greyscale.

2. Make b+w. Increase gamma contrast for Red channel fully. Click 'Apply'.

3. Segment. MENU: Process > Segmentation. Set Green channel to '105'. Save Image.

4. Outline tissue and fill in black. As described in Method 1. By hand outline any parts of tissue edge that have not been filled in, and then do 'Fill'. (select 'New AOI' on tool bar then 'Auto trace' tool. Select 'trace' rather than wand, and draw by hand an outline on the parts that have not been outlined, then fill this in).

5. Outline the tissue, now filled in. As described in ' $A$ '.

6. Measure the area. Also described in 'A'.

C. AREA (MEAN SIZE) OF ONE MICROBIAL CELL

1. Open Green processed image (made $\mathrm{b}+\mathrm{w}$ ).

2. Draw rectangular ROI around some of the microbial cells in the image.

3. Measure area of these cells. MENU: Measure $>$ Count/size. Choose 'Area' as the measurement under 'Options'.

4. Export Data into MS Excel to calculate mean area of cells. On 'Measurement data' window do MENU: File > DDE to Excel.

5. In MS Excel (automatically opened when did Dynamic Date Exchange, DDE), calculate the mean area of these cells.

Repeat so obtain mean area for approimately 30 cells.

\section{CALCULATE NUMBER OF ADHERENT CELLS}

Subtract the value obtained in 'A' (area of tissue) from the value obtained in 'B' (area of tissue + adherent cells) and divide this number by the value obtained in ' $\mathrm{C}$ ' (mean size of 1 microbial cell). This will give the number of cells adhering to the surface of the tissue.

\section{METHOD 3: SURFACE COUNTS BY DILATION}

\section{A. TOTAL CELLS IN IMAGE}


Follow the steps outlined in method 1.

B. COUNTS OF CELLS IN BACKGROUND - DILATED IMAGE

1. Open the Red filled in tissue image.

2. Segment. Set to 105 . Tissue becomes white - need this because dilate function only dilates edges of bright objects.

3. Fill over dirt in background.

4. Dilate. MENU: Process > Filters. Select the following options: In the

'Morphological tab' for $\underline{\mathrm{H} \text {. pylori }}$ choose 5 Passes (dilates by 5) and for $\underline{\mathrm{C} \text {. albicans }}$ choose 10 passes (dilates by 10).

Select for both ' $5 \times 5$ circle'.

Use 'Morphological' tab and select 'Dilate'.

5. Merge with Green processed image.

6. Average.

7. Increase Gamma contrast. Only cells in the background remain visible.

8. Count cells. Select 'Auto dark objects'.

C. COUNTS OF CELLS ON TISSUE

Use tissue count obtained in Method 1.

D. CALCULATING NUMBER OF ADHERENT CELLS

Subtract the values obtained in B (Number of cells in background) and C (Number of cells on the tissue) from the value obtained in A (total number of cells in image) and this will give the number of adherent cells (cells classed as adherent that lie within the region of the image that was dilated).

\section{METHOD 4: SURFACE COUNTS BY DRAWING SPECIFIC REGION OF INTEREST AROUND ADHERENT CELLS}

\section{A. CREATE A ROI AROUND ADHERENT CELLS ONLY}

1. Open green Image and Red+Green Image alongside it - reasons stated on other package protocols.

2. Increase Gamma contrast of Green channel (so can see green clearly) and press 'Apply'.

3. Threshold. MENU: Process $>$ Segmentation. Select green channel and set so decreases the background noise. Press 'Apply Mask' and 'Close'.

4. Draw AOI around adherent cells - Use 'Irregular AOI' tool on the 'trace' option. Click with Right mouse button to end trace.

5. Count cells. MENU: Measure $>$ Count/size. Choose 'Auto dark objects' because cells have become black after segmentation. Press 'Count'.

6. Separate clusters/clumps. On the Count/Size window do MENU: Edit > Autosplit. Then MENU: Edit > Watershed split.

B. MEASURE LENGTH/PERIMETER OF EPITHELIUM - the part on which the adherent cells were counted.

1. Outline with the 'Trace' tool the tissue part of the Red filled image.

2. Select 'perimeter' on the count/size window MENU: Measure $>$ Select

Measurements.

3. In the 'Options' section select: Borders 'none' and fill holes 'off'. 
4. In the count/size window select View: Measurement data. The perimeter length is displayed (in pixels).

NOTE: The measurement doesn't include the edge of the window, only the surface of the tissue, so don't need to subtract the lengths of the unwanted areas measured from the total.

\section{IMAGE ANALYSIS PROTOCOLS - METAMORPH}

The software package 'MS Photoeditor' is also needed for 3 steps of the image processing.

\section{METHOD 1: SURFACE COUNTS BY MERGING IMAGES (NORMAL COUNTING METHOD)}

\section{A. PROCESS THE RED IMAGE}

1. Open MS Photoeditor.

2. Open Red (PI) Image.

3. Make Red brighter. MENU: Image > Balance. Adjust the Gamma channel so red is brighter only on the PI stained tissue part of the image (not background as well). 4. Make Greyscale. MENU: File > Properties > Image Type. Select 'Greyscale 8BIT' from drop-down menu.

5. Sharpen. MENU: Effects $>$ Sharpen (choose strength as 6).

\section{Save.}

7. Open this Red greyscale image in Metamorph.

8. Fill tissue in grey. Use threshold tool on side of Image window, do Auto Threshold for light objects.

Draw ROI boxes and fill by MENU: Display $>$ Graphics $>$ Paint Region.

Select colour that matches e.g. Grey level 65 and 'Inside region area'. Press

'Paint'.

9. Outline the Tissue. MENU: Regions $>$ Create Regions around objects. Click on black (background) part of image and then the grey tissue part of image is outlined. 10. Fill this all in. Click on tissue so outline becomes active and Fill as before. Fill backgound in black. Then Threshold. MENU: Measure > Threshold Image (adjust so all tissue is included).

NOTE: Colour combine (step of merging images used later on) does not work on binarised images, so binarise images later on. 


\section{B. PROCESS THE GREEN IMAGE}

1. Make Greyscale. Open in MS Photoeditor and follow same steps as for Red Image but exclude step 4, because the cells are already bright enough. Save Image.

2. Turn cells white so can be counted later on (Software only counts white particles). Click on Contrast tool on side of Image window. Select 'Auto-

enhance'

3. Threshold. Adjust so all the cells are included.

4. Fill in any areas of dirt/noise. Use 'Irregular AOI' tool, click on 'trace/wand' and draw line around part of image to fill in. Double click to finish trace. Then fill in by procedure described earlier.

\section{COUNT TOTAL CELLS IN IMAGE}

1. Open the Green processed Image.

2. Threshold (set to 30) and Binarise.

3. Count cells. MENU: Apps $>$ Count Cells.

4. In 'Count cells' dialog box click on 'configure' and select the first option....

'counts of single objects....' Check the 'display result imsge' box.

5. In image window, click on the colour of the cells to be counted (click on 1 cell).

6. Press 'Measure' in the count cells dialog box.

7. Result is displayed in dialog box and on screen.

\section{COUNT CELLS IN BACKGROUND ONLY}

1. Open the Red-grey image and threshold.

2. Fill in tissue in red (MENU: Graphics > PAINT REGION. Choose 'Inside region area' and 'Inside threshold') and background in black (MENU: Display > Graphics > PAINT REGION. Choose 'Outside region area' and 'Value from Variable').

3. MENU: Regions $>$ Clear Regions and binarise. Make tissue an active ROI (MENU: Regions $>$ Create regions around objects'. Click on the tissue part of the image). Copy the image.

4. Open Green-grey image. Make $b+w$ (Auto-enhance contrast, threshold and binarise).

5. Paste ROI image of tissue onto the green (binarised) image of the cells.

6. Fill in the transferred image and 'Clear Regions'. This allows adherent cells to merge with the tissue and so a count of cells in the background only is obtained.

7. Count cells.

\section{E. COUNT CELLS IN TISSUE ONLY}

1. Use the red-filled image (as above; background black and tissue red).

2. Create an ROI around the tissue (MENU: Regions $>$ Create Regions around objects).

3. Fill background in red (MENU: Display $>$ Graphics $>$ PAINT REGION. Choose 'Outside region area' and 'Inside Threshold') and the tissue in black (MENU: Display $>$ Graphics > PAINT REGION. Choose 'Inside region area' and 'Value from Variable').

4. MENU: Regions $>$ Clear regions. MENU: Regions $>$ Create Region around objects. Click on the background (now red).

5. Select the thresholded green-grey image and click on this image. Transfer region. MENU: Regions > Transfer region. The region selected on the red image now becomes superimposed.

6. Don't fill in the transferred image. Make the background black and this will allow a 
count of cells on the tissue only.

7. Clear regions, binarise and Count cells.

\section{F. CALCULATE NUMBER OF ADHERENT CELLS}

Take values obtained in ' $D$ ' (number of cells in the background) and ' $E$ ' (number of cells in the tissue) and subtract these from the value obtained in ' $\mathrm{C}$ ' (Total cells in image) to give number of adherent cells on the tissue surface.

\section{METHOD 2: SURFACE COUNTS BY MERGING IMAGES (STANDARD AREA COUNTING METHOD)}

Follow the procedures outlined in Method 1, except when it comes to counting cells, in the Count Cells dialog box click on 'Configure' and select the $2^{\text {nd }}$ option, the method that counts cells using a standard area (the mean area) of a single cell, in order to divide and count the number of cells in clusters/clumps as well as single discrete cells. Press 'next' and enter in the 'Standard area' spin box the average size (Standard area) of a cell, calculated by the procedure outlined below.

\section{OBTAINING THE STANDARD AREA OF A CELL}

1. Open the Green Image made greyscale.

2. MENU: Apps $>$ Count Cells $>$ Configure $>$ Set Counting Method as 'Use Standard area to estimate objects in a cluster' $>$ Next

3. Turn Cells White. Contrast tool $>$ Auto enhance contrast.

4. Threshold. Adjust so that all cells are included (MENU: Measure $>$ Threshold Image).

5. Binarise.

6. Draw an ROI around lots of single cells using ROI tools.

7. Measure. MENU: Measure > Integrated Morphometry Anlysis (IMA). Set up the parameters for measuring as Area and Pixel area. Click in the ROI on the image so that it becomes active so the cells can be measured. Press 'Measure' in the IMA window.

8. In the IMA window click on 'display' and choose 'Summary' from the drop-down menu. This gives mean and SD of the area of cells counted. Alternatively look in the count cells window (MENU: Apps > Count cells) and the standard area of one cell has been added (Look in Configure $>$ Set Counting method $>$ 'Use standard Area....' of the count cells dialog box)

9. Then when doing the actual counting, enter the Standard Area obtained. (From the 'Measure' menu, choose 'Configure object Standards'. In the window that appears enter the mean area that was calculated, enter the value in the 'Standard Area' box. Then choose 'ok'). All clumps/clusters of cells will now be divided by this number, to give the composite number of cells in the cluster.

\section{METHOD 3: SURFACE COUNTS BY DILATION (NORMAL COUNTING METHOD)}

\section{A. PROCESS THE RED IMAGE - DILATE}


1. Open Red Greyscale filled image.

2. Fill over any dirt on the image in black.

3. Threshold and Binarise.

4. Dilate. MENU: Process > Binary. Select 'Dilate'. Choose 'Neighbourhood' as 1

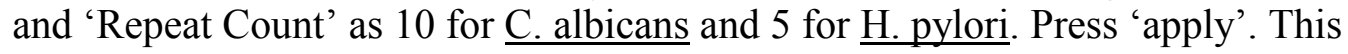
dilates by 10 pixels and 5 pixels respectively.

\section{B. COUNT TISSUE+ ADHERENT CELLS}

1. Invert the Processed Red binarised image, so background fills in white.

2. Create ROI of this background - as before, MENU: Regions > Create Regions around objects. Click on this background to activate the ROI.

3. Copy and Paste this background onto the binarised Green greyscale Image.

MENU: Regions > Transfer region. Fill the ROI in white MENU: Display > Graphics

$>$ Paint Region. Select Grey Value 1 and Paint within Region Area.

4. Count cells. Use Normal method, for both 5x and 10x pixel dialtion.

\section{COUNT CELLS ON TISSUE}

Use counts previously generated/obtained by merging filled tissue with the processed Green image (Method 1).

D. CALCULATE NUMBER OF ADHERENT CELLS

Subtract values obtained in $\mathrm{C}$ from values obtained in $\mathrm{B}$.

\section{METHOD 4: SURFACE COUNTS BY DILATION (STANDARD AREA COUNTING METHOD)}

As for Method 3 but obtain counts using the Standard area method of counting.

\section{METHOD 5: SURFACE COUNTS BY AREA}

\section{A. AREA OF TISSUE}

1. Use tissue image that has been filled in with red.

2. Cover up any 'noise' in the background with black.

3. Threshold (set to 30) and binarise - so that the tissue becomes white.

4. Outline the tissue. Menu: Regions $>$ Create regions around objects. Click in white tissue so the ROI becomes active.

5. Measure. MENU: Measure $>$ Region measurements. Select 'Area' on the 'configure' tab. Click on 'measurements' tab and the measured results can be viewed. If do MENU: Measure > Show Region Statistics, can check that the measurements are correct because the height and width of the ROI measured, is displayed.

\section{B. AREA OF TISSUE + ADHERENT CELLS}

1. Fill in the Red+Green Image.

2. Open in MS Photoeditor.

Sharpen. Menu: Effects $>$ Sharpen.

Make Red clearer. MENU: Image > Balance. Increase Gamma contrast to make the red clearer so can get better outline when come to fill in the image 
later on.

Make Greyscale. MENU: File > Properties > Image Type. Select 'Greyscale

8-BIT' from drop-down menu.

Save.

3. Open this greyscale Image in Metamorph.

4. Threshold (set to 30). Some images, ( e.g. $10^{7}$ ), can't see edges very well when threshold at 30, so use Threshold tool on side of image window select 'Autothreshold for light objects'. This doesn't increase the sizes of cells/edges of tissue, so is fine to use.

5. Binarise and Fill over any dirt on the image.

6. Create ROI around tissue and adherent cells now filled in.

FOLLOW ALL SAME STEPS AS FOR 'A'.

Merge the green binarised image with the red filled image by copy and paste (as in Method 3, 'B'). Measure the area of this to get the area of tissue+adherent cells.

\section{CALCULATE THE NUMBER OF ADHERENT CELLS}

1. Subtract the value obtained in ' $A$ ' from the value obtained in ' $B$ ' to give the AREA of adherent cells.

2. Divide this area by the mean area (or Standard area) of 1x micro-organism (cell), to give the NUMBER of adherent cells.

\section{METHOD 6: SURFACE COUNTS BY DRAWING SPECIFIC REGION OF INTEREST AROUND ADHERENT CELLS (NORMAL COUNTING METHOD)}

\section{A. CREATE AN ROI AROUND ADHERENT CELLS ONLY}

1. Open the Green greyscale Image - make black and white.

2. Make pixels white so can count - click on contrast tool on side of image window and press 'auto enhance'.

3. Threshold. MENU: Measure $>$ Threshold Image. Adjust so white turns red (overlay colour) but size of cells does not get larger, use magnifying glass tool to check this.

4. Binarise. MENU: Process $>$ Binary. Select 'Binarise' and click 'Apply'.

5. Draw ROI around adherent cells. Use 'Trace Region' tool on tool bar. Refer to the Red+Green image to see which are the adherent cells to be included in the ROI. 6. Count cells. MENU: Apps > Count cells. Set up as usual. Click on a cell in the ROI so the ROI becomes active (flashes).

7. Measure. Click 'Measure'.

B. MEASURE LENGTH/PERIMETER OF EPITHELIAL SURFACE - the part on which the adherent cells were counted.

1. Open red greyscale image filled in.

2. Fill in or over parts of image tissue that don't want the length of, with boxes calculate as for NIH-Image.

3. Outline tissue. MENU: Regions $>$ Create Regions around objects. Click on tissue. 4. Get Measurements. MENU: Measure $>$ Region measurements. Click on tissue to activate region. 
METHOD 7: SURFACE COUNTS BY DRAWING SPECIFIC REGION OF INTEREST AROUND ADHERENT CELLS (STANDARD AREA COUNTING AREA METHOD)

As for Method 6, but obtain counts using the Standard area method of counting.

\section{MEASUREMENT OF LENGTH OF EPITHELIAL SURFACE - TO CALCULATE NUMBER OF ADHERENT CELLS PER UNIT LENGTH OF TISSUE}

1. Open Red Image.

2. Threshold (MENU: Measure > Threshold Image).

3. Fill tissue in red.

Draw ROI boxes and fill by MENU: Display > Graphics >Paint Region. Select colour 'Red' and 'Inside region area'. Press 'Paint'.

4. Outline the Red Image. MENU: Regions $>$ Create Regions around objects. Click on black (background) part of image and then the red tissue part of image is outlined. 5. Fill this all in. Click on tissue so outline becomes active and Fill as before.

6. Then Threshold and binarise.

7. Measure. MENU: Measure $>$ Region Measurements. Select 'Include: Active Region'.

Select 'Area' and 'Distance'.

8. Remove from the value obtained, the lengths of the parts of the image not wanted to be included in the measurement, i.e. the edges of the image. Do this by placing the pointer on the edge of the image and obtaining the $\mathrm{X}-\mathrm{Y}$ coordinates (i.e. Pixel no./length) of the line want to subtract from the total. Zoom in to be more accurate. 
